\title{
Connections Betwen Trust in Journalism and Patterns of Media Use
}

\author{
Sašo Slaček Brlek* \\ Jožica Zajc ** $^{*}$ \\ Boris Mance ${ }^{* * *}$
}

\section{SUMMARY}

The article investigates the connections between trust in journalism and media use. The authors find that the connection between frequency of media use for informative purposes and trust in journalism is very weak, being statistically significant at the 0.05 level for television viewing but not for radio listening, newspaper reading or use of the internet. The authors find indications of polarisation along partisan lines, since those respondents who follow right-wing media (especially those associated with the Slovenian Democratic Party) exhibit a lower level of trust in journalism.

Key words: trust in journalism, media fragmentation, partisan polarisation, news consumption

\section{Introduction}

The current transformations occurring in journalism can appropriately be called revolutionary since they mean that "almost every aspect of production, reporting

\footnotetext{
* Sašo Slaček Brlek is a researcher at the Social Communications Research Centre at the Faculty of Social Sciences, University of Ljubljana, Slovenia.

E-mail: saso.brlek-slacek@fdv.uni-lj.si

** Jožica Zajc is a researcher at the Centre for Organisational and Human Resources

Research at the Faculty of Social Sciences, University of Ljubljana, Slovenia.

E-mail: jozica.zajc@ffdv.uni-lj.si

*** Boris Mance is a researcher at the Social Communications Research Centre at the Faculty of Social Sciences, University of Ljubljana, Slovenia.

E-mail: boris.mance@fdv.uni-lj.si
} 
Medij. istraž. (god. 22, br. 1) 2016. (41-63)

and reception of news is changing" (Franklin, 2014: 481). Digital technologies have the potential to provide audiences access to information from a more diverse array of sources. The role of traditional gatekeepers of information is being challenged by bloggers, citizen journalists and new institutional players like Google and Facebook.

At the same time, the media industry is facing financial difficulties resulting from declining numbers of readers, listeners and viewers, declining advertising revenues and the consequences of economically unviable technological innovations in the sphere of journalistic production (Jones and Salter, 2012; Grueskin et al., 2012). Institutional journalism is facing trends of commercialisation and pauperisation (Splichal, 2014) to the degree that the ability of journalism to perform its social functions is being called into question (e.g., Blumler, 2010; Habermas, 2014).

Digital technologies and the proliferation of new sources of information have already stimulated scholarly interest in issues of trust and credibility (Metzger et al., 2003: 293). Yet digital technologies are not merely an additional channel, as was implied in early studies that attempted to measure the relative credibility of online news compared to other channels of communication (e.g., Johnson and Kaye, 1998; 2004; 2009; Kiousis, 2001). Rather, digital technologies are contributing to the fundamental reshaping of journalism and news media. Those who study of issues of trust and credibility of messages, sources and media must follow suit and treat the changes happening under the influence of new technologies holistically, exploring the association between sources of information, topics of interest and channels of media use.

\section{Fragmentation and the rise of partisan media}

The era of journalism known as "high modernism," which was rooted in the ideas of professional autonomy, objectivity and distance from commercial and political pressures, started to decay in 1980s (Hallin, 2006). This occurred first as a consequence of ever-growing commercialisation in the media and second by advancement of technological innovation (especially the internet), which led to audience segmentation and fragmentation of mass media (Mancini, 2013: 44). In order to better fit the topics of interest of the individualised media customer, the traditional mass audience has been broken down by processes of audience segmentation (Katz, 1996; Chaffee and Metzger, 2001). These processes of segmentation have appeared in the classic media (e.g., newspapers and traditional analogue television), which used to cover the interests of a general audience but have been divided into segments, whereas fragmentation was inherent to the internet from the beginning due to its network structure (Bohman, 2004). Segmentation of audiences and fragmenta- 
tion of communication channels are similar processes as they both lead to "demassification" of the audience (Chaffee and Metzger, 2001: 369).

Patterns of media use in the past, due to the relatively small number of media outlets, were fairly predictable - most people tend to return again and again to the same media outlets. However, such previously predictable media use has changed and continues to change with the advent of new communication technologies (Moody, 2011). The internet enables users to select what they wish to be informed about, how they wish to be informed and how often (hourly, daily, weekly). As internet technologies continue to free us from fixed scheduling, we can expect patterns of media use to become even less uniform (Moody, 2011).

While some researchers emphasise positive characteristics of fragmentation, such as the availability of the numerous sources of information and the resistivity of the internet to exertion of control (Fenton, 2010), others emphasise that its ability to empower the audience in the production of news (e.g., participatory and civic journalism) comes at a price as this can, among other things, "deinstitutionalise" classical journalism to a certain degree (Russial et al., 2015). The processes of "disintermediation" (Chadwick, 2006) - the undermining of the "common meeting ground and debate [of] contrasting views" (Mancini, 2013: 51) - means that the classic media's role in enabling reflective and objective coverage of important political issues and putting them on a public agenda for further public scrutiny and deliberation, in analogy to the classic idea of the public sphere, is disintegrating. This may have dramatic consequences for democratic processes (Bohman, 2004; Katz, 1996) as we will develop further.

The fragmented media environment seems to be more benevolent in nursing selective media exposure and communication among citizens with similar opinions or partisan lines (Stroud Jomini, 2011). Plurality of content might have beneficial consequences insofar as it provides exposure for content that is ignored or underrepresented in the mainstream media. For example, research on Swedish political activists shows that they use the internet to seek out political information that they believe to be free of distortion by mainstream media. From the points of view of political party and activist group websites, the media hardly covers the most relevant issues and gets them wrong when it does (Dahlgren and Olson, 2005: 15).

On the other hand, selective exposure can be a way to avoid the effort one would potentially have to invest in dealing with cognitive dissonance - that is, coping with information contradictory to one's belief system (Stroud Jomini, 2011). The choice of avoiding discomfort by engaging with likeminded information sources means undermining the process of "social integration that could foster necessary negotiations and agreements" (Mancini, 2013: 50). This leads to existing opinions being reinforced and, consequently, contributes to social and political polarisation (Sun- 
stein, 2001; Conover et al, 2011). "These niche audiences are characterised by the so-called 'echo chamber' (Sunstein, 2001) attitude: they are self-referential and may be less available to establish collaborations and coalitions with other groups" (Mancini, 2013: 56).

While citizens still use an array of different media outlets, there are indications that the partisan media audience is growing. "Citizens with consistent ideological views on the left and right have information streams that are distinct from those of individuals with more mixed political views and have also a greater impact on the political process than do those with more mixed ideological views" (Mitchell et al., 2014). The question of partisan news actors as political actors (at least in the Slovenian case) is an under-researched field. Nevertheless, a modest study on this phenomenon has been conducted in the context of Slovenia, and evidence has been provided that coalitions between particular partisan media actors and political parties nurse the development of the "echo chamber" effect (Mance, 2014). Insofar as media fragmentation and audience segmentation determine, to a certain extent, persons' information sources and salient topics, what kind of impacts can we expect these trends to have on trust in journalism? This leads us to our first two research questions:

RQ1: How does trust in journalism vary according to the topics respondents have followed most?

RQ2: How is trust in journalism connected with the use of specific sources of information?

\section{Trust and attitudes}

In the broadest sense, "trust" can be defined as an expectation of benevolent behaviour in a situation of uncertainty. According to Luhmann (1968), trust can be seen as an asset for the reduction of social complexity and a way of dealing with risks, while distrust is a qualitative contrast of trust. Trust is oriented toward the future (the nearly endless number of possible events) and draws on information from the past in order to reduce this multitude of possible events to a manageable number of probable events (Ibid.). It is a feature attributed to one or more individuals, institutions or their products by somebody with regard to something (Nah and Chung, 2011), so it can be individual, interpersonal or organisational.

Even though the phenomenon of trust is being studied by numerous researchers across many disciplines, there is no consensus on its definition. Even the question of how one should reach a definition of trust receives different answers; some scholars proceed from theory and attempt to arrive at a definition deductively, while others 
proceed inductively by studying and cataloguing people's everyday understanding of trust. While some researchers perceive it as a one-dimensional concept with a common meaning, others hold that it is composed of multiple components. In their comprehensive literature review, McKnight and Chervany (1996) found that different authors define trust as a combination of one or more of the following attributes: competence, expertise, dynamism, predictability, goodness or morality, benevolence (or caring or concern), responsiveness, honesty, credibility, reliability, dependability, openness or open-mindedness, caution or safety consciousness, shared understanding, personal attraction and goodwill.

In the context of studying trust in journalism/journalists, scholars use either of two terms - "trust" or "credibility" - to describe a positive perception of the source of information, although credibility is elsewhere defined as the communicative dimension of the broader concept of trust, the meaning of which is more extensive (Nah and Chung, 2011). Credibility research has been a major part of mass communication scholarship since the field's earliest days (Kiousis, 2001). Some researchers define media credibility as believability (Mulder, 1980), a concept that includes accuracy, fairness, completeness, reliability and trustworthiness (Metzger et al., 2003). However, the core dimensions of the concept of media credibility have never been agreed upon (Kiousis, 2001).

Media credibility as a concept has been approached by two main scientific flows, which differ on the basis of treating the phenomenon as being source or medium oriented. Early media credibility research focused on the problem of opinion change due to credibility of a source and the consequent acceptance of the source's message (Hovland and Weiss, 1951). This research domain looked at the phenomenon as dependent almost exclusively on characteristics of the sources, such as their expertise and trustworthiness; analogically, media credibility was defined as the "attitude of the audience toward the communicator" (ibid., 635). The approach has been questioned from several angles, the most prominent being its oversimplification (Markham, 1968) and one-dimensionality combined with the lack of a theory, which caused its unsuitability for empirical testing (Berlo et al., 1969). Subsequent research widened the explanatory factors with the inclusion of "the impact of content and message attributes on source" (Kiousis 2001, 382) and suggested that source credibility should be understood from the receiver's point of view (Gunther 1992; Kiousis, 2001; Browning and Sweetster, 2014). Most prominent inquiries regarding source credibility have been by dominated by research on the impact of political candidates, individual journalists and online sources on audiences' perception of credibility (Kiousis, 2001).

The other research domain evolved from thinking that ascribed perceived credibility to various media channels (Rimmer and Weaver, 1987). This approach stemmed 
from the work of Westley and Severin, where "perceived credibility" was analysed through a person's media use, according to which trust in media correlates positively with the intensity of media use (Westley and Severin, 1964; Johnson and Kaye, 2009). The field of research on media credibility had shifted its focus to the channel through which content is delivered rather than the sources of the content (Kiousis, 2001); credibility "is not a characteristic inherent in a source, but a judgment made by the users themselves" (Johnson and Kaye, 2009).

Emerging from earlier studies, traditional media sources, such as newspapers and television, have generally been considered the most credible sources of the news (Abel and Wirth, 1977; Gaziano and McGrath, 1986; Metzger and Flaganin, 2000), and television news was typically deemed more credible than print news (Westley and Severin, 1964). Although scholars have often found that primarily informative media is seen as more credible than entertainment media (Johnson et al., 2007; Metzger et al., 2003), the findings are not unanimous. Entertainment media may be perceived as more credible than information media because viewers are not socialized to search for credibility concerns while engaging with entertainment media (Mulder, 1980). It has also been found that humour could positively affect credibility assessments - humour increases positive affect, and positive affect increases credibility (Skalski et al., 2009). At this point, we pose our third research question:

\section{RQ3: How is trust in journalism connected with channel use?}

While earlier approaches focused particularly on the comparison of TV and newspaper news credibility (Newhagen and Nass, 1989), the introduction (and normalisation) of the internet caused the division to be reconsidered. Credibility was once more an issue of importance in terms of source and channel (Thorson and Moore, 1996), and convenient access to information was a new predictor added to the understanding of media use and credibility (Metzger, Flanagin and Zwarun, 2003). Namely, people regularly use media that they do not trust to find out about politics, and thus convenience is prioritised over credibility in information selection (Moody, 2011). Individuals can seek information by alternative, so-called "non-news media information sources" (Moody, 2011), such as interpersonal communication, social networking websites (e.g., Facebook), direct communication with social actors or interest groups and active engagement with internet search engines (e.g., conducting a Google search) (Moody, 2011). Non-news media sources are distinguished from media sources according to their degree of content mediation and consumption costs. Media sources are more overtly mediated than non-news media sources, involving a professional information gatekeeper, such as an editor. This mediation may support journalistic integrity, but it may also be used to ensure that media content reflects the business or political interests of media proprietors, over and above 
fourth estate ideals, as echoed in the accuracy and bias concerns of politically interested audiences (Moody, 2011). On the other hand, non-news media sources involve greater consumption costs than news-oriented media sources. Seeking, obtaining and processing information requires resources such as money, time, energy and cognitive effort, as well as opportunity costs (Moody, 2011). Interpersonal communication may also be relevant to differences in perception of trust and may account for the limited impact of media use on trusting sources (Chaffee, 1972; 1982; McLeod et al., 1968).

As people's attitudes on a number of topics become more polarised in any direction, their credibility in journalistic coverage of those issues declines (Gunther, 1992). The individual's personal stake in a topic is connected with their judgements about the credibility of journalism. The elaboration likelihood model (Petty and Caccioppo, 1986) proposes that highly involved people do more message elaboration and think more about the contents of a message because their greater personal concern gives them more reason to seek correct information and opinions. People who are highly involved with a topic are also likely to have more fixed and firmly held positions on the topic, more polarised attitudes on the topic, more prior knowledge, more self-perceived expertise on the topic, more experience with thinking, discussing, or arguing the topic and more intense personal interest in the topic. Highly involved people have the ability and motivation to undertake "biased processing" their prior opinion on a subject steers their perceptions and processing of messages in such a way as to allow them to maintain their original opinion. The biased processing goes by 1) taking constant information (that which falls into a narrow range of acceptance) as simply veridical and embracing it, and 2) judging counter-attitudinal information to be the product of biased, misguided or ill-informed sources and rejecting it (Petty and Caccioppo, 1986; Gunther, 1992). In this manner, audience assessments of credibility are commonly explained as the results of individuals' sceptical disposition, either toward journalism in particular or as a general trait (Gunther, 1992). Besides, credibility is not a trait that people ascribe consistently to a channel; rather, it is a highly situational assessment (Berlo et al., 1969; Gunther, 1992). Furthermore, news-focused sources in mass media are not the only sources of information. Lack of trust in journalism could, therefore, lead to the use of alternative sources of information. This could involve seeking information in new, nontraditional media, such as the internet, or even outside of the mass media, such as personal contact. The tendency of highly involved people to demonstrate a greater resistance to persuasion (Hovland and Weiss, 1951), and the tendency of people with strong attitudes to become more polarised after processing balanced, two-sided information on the topic, demonstrate a resistance mechanism called "correction for incredulity" (Osgood and Tannenbaum, 1955). 
Medij. istraž. (god. 22, br. 1) 2016. (41-63)

Our study of trust in journalism does not include only traditional mass media (e.g., television, newspapers, radio) but also takes into consideration the increasingly complex information environment by including new media channels (e.g., the internet) and non-news media sources (e.g., interpersonal communication, social networks).

\section{Methodology}

This study analyses a survey about trust in journalism and the use of media that was conducted within the project Journalism and the Internet: Political, Economic and Cultural Aspects of the Technological Transformation of Modern Journalism. The data was collected using a questionnaire (the CATI method) on a representative sample of citizens of Slovenia $(\mathrm{N}=500)$ between June 19 and July 6, 2015.

Our operationalisation of trust in journalism is derived from Matthes and Kohring (2001), who propose a four-dimensional operationalisation of trust in journalism based on a systems-theoretical background. The term "trust in media" is more commonly used in the scholarly literature, yet we believe "trust in journalism" to be more precise. Namely, the term trust in media is used to refer to mass media as sources of information, not to its artistic or entertainment value. We will therefore use the term trust in journalism through the remainder of the article instead of the more common term trust in media.

Matthes and Kohring define trust as "selective coupling of the actions of others with one's own actions under conditions of a rationally not justifiable tolerance of uncertainty" (Ibid.: 10). In the case of journalism, they propose four dimension of trust: 1.) trust in the selection of topics, 2.) trust in the selection of facts, 3.) trust in correctness of descriptions (which they equate with credibility) and 4.) trust in journalistic opinions (Ibid.: 11). They tested the scale by asking respondents to rate the performance of the news media on a single topic (the Euro), which was chosen by the authors. In order to account for different patterns of news consumption and salience of different topics among audience members, we modified this approach slightly by first asking respondents to name the topic that they have been following most intensively recently ${ }^{1}$ and then asking them to state their agreement or disagreement with the following items on a five-point scale:

\section{Analysis}

To check whether our data exhibits a similar latent structure to that found by Matthes and Kohring (2001), we have conducted an exploratory factor analysis. We chose to extract a four-factor solution, which corresponds to the four theoretical dimensions of trust in journalism. 
Table 1. Trust in journalism scale (adapted from Matthes and Kohring, 2001)

Tablica 1. Skala povjerenja u novinarstvo (prilagođeno prema Matthesu i Kohringu, 2001)

\begin{tabular}{|c|c|c|}
\hline Dimension of credibility & Sub-dimension & Item \\
\hline \multirow[t]{3}{*}{ Trust in selection of topics } & & $\begin{array}{l}\text { [Media] are devoting appropriate } \\
\text { attention to this topic. }\end{array}$ \\
\hline & & $\begin{array}{l}\text { Reporting on this topic is frequent } \\
\text { enough. }\end{array}$ \\
\hline & & $\begin{array}{l}\text { They should have covered this topic } \\
\text { earlier. }\end{array}$ \\
\hline \multirow[t]{4}{*}{ Trust in selection of facts } & & $\begin{array}{l}\text { Media reporting is covering all } \\
\text { possible implications of this question. }\end{array}$ \\
\hline & & $\begin{array}{l}\text { When reporting on this topic, the } \\
\text { media are taking different viewpoints } \\
\text { into account. }\end{array}$ \\
\hline & & $\begin{array}{l}\text { Reporting about this topic is } \\
\text { one-sided. }\end{array}$ \\
\hline & & $\begin{array}{l}\text { When reporting on the topic, the } \\
\text { media are focusing on irrelevant } \\
\text { things. }\end{array}$ \\
\hline \multirow[t]{7}{*}{$\begin{array}{l}\text { Trust in correctness of } \\
\text { descriptions (credibility) }\end{array}$} & \multirow[t]{4}{*}{$\begin{array}{l}\text { Truthfulness } \\
\text { of information }\end{array}$} & $\begin{array}{l}\text { Media reporting represents the events } \\
\text { truthfully. }\end{array}$ \\
\hline & & $\begin{array}{l}\text { Information I receive from the media } \\
\text { about this topic is reliable. }\end{array}$ \\
\hline & & $\begin{array}{l}\text { Information I receive from the media } \\
\text { about this topic are credible enough } \\
\text { that I can pass it on. }\end{array}$ \\
\hline & & The media show the whole picture. \\
\hline & \multirow[t]{3}{*}{$\begin{array}{l}\text { Completeness } \\
\text { of information }\end{array}$} & $\begin{array}{l}\text { The media convey all the information } \\
\text { I need about this topic. }\end{array}$ \\
\hline & & $\begin{array}{l}\text { The media are ignoring important } \\
\text { background information. }\end{array}$ \\
\hline & & $\begin{array}{l}\text { By following the media, I can get the } \\
\text { complete picture about this topic. }\end{array}$ \\
\hline \multirow[t]{4}{*}{ Trust in journalistic opinions } & & $\begin{array}{l}\text { Comments of journalists about this } \\
\text { topic are useful. }\end{array}$ \\
\hline & & $\begin{array}{l}\text { Journalists express their critiques in } \\
\text { an inappropriate manner. }\end{array}$ \\
\hline & & $\begin{array}{l}\text { Opinions of journalists on this topic } \\
\text { are very interesting. }\end{array}$ \\
\hline & & $\begin{array}{l}\text { Opinions of journalists on this topic } \\
\text { are well founded. }\end{array}$ \\
\hline
\end{tabular}


Medij. istraž. (god. 22, br. 1) 2016. (41-63)

Table 2. Factor loadings for trust in journalism (principal axis factoring, oblimin rotation with Kaiser normalization)

Tablica 2. Faktori koji čine povjerenje u novinarstvo

\begin{tabular}{|c|c|c|c|c|c|}
\hline \multirow{2}{*}{ Item } & \multirow{2}{*}{$\mathbf{h}^{2}$} & \multicolumn{4}{|c|}{ Factor loadings (pattern) } \\
\hline & & 1 & 2 & 3 & 4 \\
\hline $\begin{array}{l}\text { Media are devoting appropriate attention to } \\
\text { this topic. }\end{array}$ & 0,546 & 0,020 & 0,109 & 0,702 & $-0,041$ \\
\hline Reporting on this topic is frequent enough. & 0,533 & 0,006 & $-0,074$ & 0,736 & 0,045 \\
\hline They should have covered this topic earlier. & 0,161 & $-0,047$ & 0,401 & 0,060 & $-0,134$ \\
\hline $\begin{array}{l}\text { Media reporting is covering all possible } \\
\text { implications of this question. }\end{array}$ & 0,281 & 0,382 & $-0,019$ & 0,176 & 0,111 \\
\hline $\begin{array}{l}\text { When reporting on this topic, the media are } \\
\text { taking different viewpoints into account. }\end{array}$ & 0,250 & 0,294 & 0,121 & 0,132 & 0,124 \\
\hline Reporting about this topic is one-sided. & 0,406 & 0,088 & 0,591 & 0,044 & $-0,036$ \\
\hline $\begin{array}{l}\text { When reporting on the topic, the media are } \\
\text { focusing on irrelevant things. }\end{array}$ & 0,301 & 0,052 & 0,526 & 0,000 & $-0,003$ \\
\hline $\begin{array}{l}\text { Media reporting represents events } \\
\text { truthfully. }\end{array}$ & 0,465 & 0,540 & 0,248 & $-0,065$ & 0,043 \\
\hline $\begin{array}{l}\text { Information I receive from the media about } \\
\text { this topic is reliable. }\end{array}$ & 0,370 & 0,141 & 0,451 & 0,011 & 0,175 \\
\hline $\begin{array}{l}\text { Information I receive from the media about } \\
\text { this topic is credible enough that I can pass } \\
\text { it on. }\end{array}$ & 0,459 & 0,491 & 0,270 & 0,007 & 0,046 \\
\hline The media show the whole picture. & 0,667 & 0,884 & $-0,110$ & 0,033 & $-0,078$ \\
\hline $\begin{array}{l}\text { The media convey all the information I need } \\
\text { about this topic. }\end{array}$ & 0,579 & 0,708 & 0,037 & 0,044 & 0,036 \\
\hline $\begin{array}{l}\text { The media are ignoring important } \\
\text { background information. }\end{array}$ & 0,263 & 0,083 & 0,465 & $-0,031$ & 0,050 \\
\hline $\begin{array}{l}\text { By following the media, I can get the } \\
\text { complete picture about this topic. }\end{array}$ & 0,440 & 0,424 & 0,012 & $-0,023$ & 0,331 \\
\hline $\begin{array}{l}\text { Comments of journalists about this topic are } \\
\text { useful. }\end{array}$ & 0,471 & $-0,024$ & 0,003 & 0,055 & 0,688 \\
\hline $\begin{array}{l}\text { Journalists express their critiques in an } \\
\text { inappropriate manner. }\end{array}$ & 0,277 & $-0,067$ & 0,422 & 0,012 & 0,290 \\
\hline $\begin{array}{l}\text { Opinions of journalists on this topic are very } \\
\text { interesting. }\end{array}$ & 0,461 & 0,072 & $-0,100$ & 0,016 & 0,652 \\
\hline $\begin{array}{l}\text { Opinions of journalists on this topic are well } \\
\text { founded. }\end{array}$ & 0,660 & 0,201 & 0,117 & $-0,002$ & 0,644 \\
\hline \multicolumn{2}{|l|}{$\%$ of variance explained by factor } & 30,60 & 9,73 & 7,84 & 5,95 \\
\hline
\end{tabular}

Op. cells with highest loading in their respective rows are shaded. 
Table 3. Factor correlation matrix for trust in journalism Tablica 3. Matrica korelacije faktora povjerenja u novinarstvo

\begin{tabular}{|l|c|c|c|c|}
\hline Factor & $\mathbf{1}$ & $\mathbf{2}$ & $\mathbf{3}$ & $\mathbf{4}$ \\
\hline $\mathbf{1}$ & 1,000 & 0,412 & 0,352 & 0,546 \\
\hline $\mathbf{2}$ & 0,412 & 1,000 & 0,255 & 0,212 \\
\hline $\mathbf{3}$ & 0,352 & 0,255 & 1,000 & 0,159 \\
\hline $\mathbf{4}$ & 0,546 & 0,212 & 0,159 & 1,000 \\
\hline
\end{tabular}

The results of the exploratory factor analysis show a different latent structure than that found by Matthes and Kohring (2001). While factors 3 and 4 correspond to two of the theoretical dimensions (trust in selection of topics and trust in journalistic opinions respectively), factor 2 seems to capture distrust cutting across all four theoretical dimensions: all of the negative items load highly on this factor, with one exception ("Information I receive from the media about this topic are reliable"). The first factor combines two conceptually similar theoretical dimensions, namely trust in selection of facts and trust in correctness of descriptions. We will refer to it henceforth as trust in journalistic objectivity.

Distrust has emerged in our data as a separate latent dimension. This finding has some theoretical foundations. Luhmann (1968: 69) has defined distrust as a qualitatively distinct functional equivalent (meaning it also serves to reduce complexity) to trust. Sztompka (1999: 26) similarly distinguishes between distrust and mistrust, where he defines distrust as "negative expectations about the actions of others" (Ibid.), while mistrust "means the lack of clear expectations, as well as hesitations about committing myself" (Ibid.).

Since the reliability of the scale as a whole is high (Cronbach's alpha is 0,851 ) and factors correlate highly among each other (see Table 3 ), we have decided to calculate a composite score for trust in journalism by computing the mean of all items. We have also calculated scores for the four factors that we have found (trust in objectivity, distrust, trust in selection of topics and trust in journalistic comments) by the same procedure. In the remainder of the article, we will focus primarily on the composite scale of trust in journalism, but we will also pay attention to variations between different dimensions.

\section{RQ1: Trust in journalism by topic}

The topics named by respondents as those they have followed most intensively were recorded verbatim and later coded into categories (see Table 4). Most respondents named a concrete topic, while five said they have been following stories about scandals or corruption without naming a specific instance. The category other includes 
Medij. istraž. (god. 22, br. 1) 2016. (41-63)

Table 4. Topics respondents followed most intensively and their level of trust in journalism by topic

Tablica 4. Teme koje su ispitanici najintenzivnije pratili i njihova razina povjerenja u novinarstvo s obzirom na temu

\begin{tabular}{|c|c|c|c|c|c|}
\hline \multirow[b]{2}{*}{ Topic } & \multirow[b]{2}{*}{ Frequency } & \multirow{2}{*}{$\begin{array}{c}\text { Valid } \\
\text { percent }\end{array}$} & \multicolumn{3}{|c|}{ Trust in journalism } \\
\hline & & & $\mathbf{N}$ & Mean & $\begin{array}{c}\text { Std. } \\
\text { deviation }\end{array}$ \\
\hline Greek public debt crisis & 127 & 26,4 & 95 & 3,13 & 0,52 \\
\hline $\begin{array}{l}\text { Privatisation of national } \\
\text { telecommunications company } \\
\text { (Telekom) }\end{array}$ & 122 & 25,2 & 94 & 3,08 & 0,52 \\
\hline $\begin{array}{l}\text { Constitutional court ruling on the } \\
\text { mandate of MP Janez Janša }\end{array}$ & 76 & 15,9 & 69 & 2,82 & 0,65 \\
\hline Corruption affair in healthcare & 60 & 12,4 & 51 & 3,00 & 0,50 \\
\hline Migration crisis in the Mediterranean & 37 & 7,7 & 35 & 3,00 & 0,58 \\
\hline $\begin{array}{l}\text { Supreme court ruling on the } \\
\text { suspension of the prison sentence of } \\
\text { Igor Bavčar }\end{array}$ & 10 & 2,1 & 7 & 2,80 & 0,46 \\
\hline Privatisation of NKBM bank & 9 & 1,8 & 5 & 3,17 & 0,56 \\
\hline Corruption /scandals & 5 & 1,0 & 5 & 2,69 & 0,61 \\
\hline Terrorist attacks in Tunisia & 4 & 0,7 & 2 & 3,13 & 0,28 \\
\hline $\begin{array}{l}\text { Former Kosovo PM Ramush } \\
\text { Haradinaj retained at Brnik airport }\end{array}$ & 3 & 0,5 & 3 & 3,49 & 1,00 \\
\hline Other & 19 & 4,0 & 13 & 3,02 & 0,78 \\
\hline Total & 482 & 100 & 386 & 3,00 & 0,58 \\
\hline
\end{tabular}

topics that were named by less than three respondents and answers that were too broad for coding (e.g., "news in general" or "current affairs"). If more than one topic was named by respondents, the first topic named was coded.

To see whether trust in media differed depending on the topic that respondents were following most intensively, we conducted a one-way ANOVA on topics with a frequency of at least five. One topic, namely the ruling of the constitutional court on the mandate of former PM and current MP Janez Janša, stands out. It is associated with the third lowest level of trust in journalism (higher only than Bavčar and the more general topic of corruption/scandals), and the difference is statistically significant at the 0.05 level in relation to one of the other topics (the Greek public debt crisis). To conserve space, the following table (Table 5) includes only comparisons with the topic of Janša since no other differences proved statistically significant at the 0.05 level. 
Table 5. Trust in journalism, One-way ANOVA, Bonferroni test

Tablica 5. Povjerenje u novinarstvo, One-way ANOVA, Bonferroni test

\begin{tabular}{|l|l|l|l|l|}
\hline (I) Topic & (J) Topic & $\begin{array}{l}\text { Mean difference } \\
\text { (I-J) }\end{array}$ & Std. error & Sig. \\
\hline \multirow{3}{*}{ Janša } & Telekom privatisation & $-0,26$ & 0,08 & 0,096 \\
\cline { 2 - 5 } & Migration crisis in the Mediterranean & $-0,13$ & 0,11 & 1,000 \\
\cline { 2 - 5 } & Greek public debt crisis & $-0,32^{*}$ & 0,08 & 0,007 \\
\cline { 2 - 5 } & Corruption in healthcare & $-0,18$ & 0,10 & 1,000 \\
\cline { 2 - 5 } & Bavčar & 0,02 & 0,19 & 1,000 \\
\cline { 2 - 5 } & Privatisation of NKBM bank & $-0,35$ & 0,20 & 1,000 \\
\cline { 2 - 5 } & Corruption/scandals & 0,13 & 0,27 & 1,000 \\
\hline
\end{tabular}

Op. * The mean difference is significant at the 0.05 level.

When looking at dimensions of trust separately, it becomes clear that distrust is the most important factor. In the dimension of distrust, the difference between the topics of Janša and the Greek public debt crisis (difference of -0,44) is statistically significant $(p=0,03)$. In the dimensions of trust in objectivity, trust in selection of topics and trust in journalistic opinions, no differences between groups are statistically significant at the 0,05 level.

\section{RQ2: Trust in journalism by source}

We used independent samples t-tests to determine whether there are any significant differences in trust in journalism depending on whether respondents follow or do not follow a specific medium. We included those media that have national reach and were named as a relevant source of information by at least 10 respondents. These include the three television programs of the public broadcaster (TV SLO 1, TV SLO 2 and TV SLO 3) and three private programs (POP TV, Kanal A and Planet TV), three of the radio programs of the public broadcaster (Prvi program, Val 202 and ARS) and two private radio programs (the mainstream commercial Radio 1 and the catholic Radio Ognjišče), five daily newspapers (Delo, Dnevnik, Večer, Slovenske Novice and Svet24), five weeklies (Finance, Mladina, Reporter, Demokracija and Nedeljski Dnevnik) and 10 internet news sites (24ur.com, siol.net, rtvslo.si, delo.si, dnevnik.si, finance.si, vecer.com, mladina.si and reporter.si). We have also included interpersonal contact and online social networks. The following table summarizes all the differences that were statistically significant at the 0,05 level.

The commercial television channel POP TV and the tabloid Slovenske Novice are positively associated with the dimension of trust in objectivity: those who follow these media exhibit a higher trust in journalistic objectivity than those who do not. 
Medij. istraž. (god. 22, br. 1) 2016. (41-63)

Table 7. T-test (trust by medium, only those differences that are significant at the 0,05 level)

Tablica 7. T-test (povjerenje s obzirom na medij, samo one razlike koje su značajne na razini 0,05$)$

\begin{tabular}{|c|c|c|c|c|c|c|c|}
\hline & Dimension of trust & \multicolumn{2}{|c|}{ Trust (mean) } & \multicolumn{2}{|c|}{$\mathbf{N}$} & \multirow[b]{2}{*}{$\mathbf{t}$} & \multirow[b]{2}{*}{ Sig. } \\
\hline Source & & Follows & $\begin{array}{c}\text { Does } \\
\text { not } \\
\text { follow }\end{array}$ & Follows & $\begin{array}{c}\text { Does } \\
\text { not } \\
\text { follow }\end{array}$ & & \\
\hline \multicolumn{8}{|c|}{ Higher trust of followers } \\
\hline dnevnik.si & Selection of topic & 4,34 & 3,60 & 15 & 479 & 3,084 & 0,002 \\
\hline POP TV & Objectivity & 2,92 & 2,66 & 313 & 130 & 3,181 & 0,002 \\
\hline \multirow{2}{*}{$\begin{array}{l}\text { Slovenske } \\
\text { Novice }\end{array}$} & Objectivity & 3,03 & 2,79 & 100 & 343 & 2,761 & 0,006 \\
\hline & Journalistic opinions & 3,58 & 3,37 & 103 & 366 & 2,486 & 0,013 \\
\hline Večer & Distrust* & 3,05 & 2,71 & 54 & 376 & 3,326 & 0,001 \\
\hline mladina.si & Distrust* & 3,33 & 2,74 & 8 & 422 & 2,383 & 0,018 \\
\hline $\begin{array}{l}\text { Personal } \\
\text { contact }\end{array}$ & Distrust* & 2,85 & 2,70 & 147 & 283 & 2,052 & 0,041 \\
\hline \multicolumn{8}{|c|}{ Lower trust of followers } \\
\hline \multirow[t]{5}{*}{ Reporter } & In general & 2,56 & 3,02 & 19 & 380 & $-3,419$ & 0,001 \\
\hline & Objectivity & 2,45 & 2,86 & 20 & 423 & $-2,378$ & 0,018 \\
\hline & Distrust* & 2,38 & 2,77 & 20 & 410 & $-2,417$ & 0,016 \\
\hline & Selection of topics & 3,07 & 3,65 & 23 & 471 & $-2,968$ & 0,003 \\
\hline & Journalistic comments & 3,02 & 3,43 & 21 & 448 & $-2,389$ & 0,017 \\
\hline \multirow[t]{5}{*}{ Demokracija } & In general & 2,37 & 3,01 & 12 & 387 & $-3,934$ & 0,000 \\
\hline & Objectivity & 2,23 & 2,86 & 12 & 430 & $-2,862$ & 0,004 \\
\hline & Distrust* & 2,17 & 2,77 & 14 & 416 & $-3,110$ & 0,002 \\
\hline & Selection of topic & 2,94 & 3,65 & 14 & 480 & $-2,833$ & 0,005 \\
\hline & Journalistic opinions & 2,84 & 3,43 & 14 & 455 & $-2,81$ & 0,005 \\
\hline \multirow[t]{2}{*}{ Finance } & In general & 2,70 & 3,01 & 17 & 383 & $-2,145$ & 0,033 \\
\hline & Objectivity & 2,31 & 2,86 & 17 & 425 & $-2,991$ & 0,003 \\
\hline finance.si & Objectivity & 2,49 & 2,86 & 17 & 425 & $-1,981$ & 0,048 \\
\hline \multirow[t]{2}{*}{ rtvslo.si } & Objectivity & 2,64 & 2,88 & 75 & 368 & $-2,576$ & 0,010 \\
\hline & Journalistic opinions & 3,20 & 3,46 & 75 & 394 & $-2,638$ & 0,009 \\
\hline TV SLO 3 & Distrust* & 2,54 & 2,79 & 58 & 372 & $-2,488$ & 0,013 \\
\hline Radio ARS & Objectivity & 2,34 & 2,85 & 10 & 433 & $-2,103$ & 0,036 \\
\hline 24ur.com & Journalistic opinions & 3,31 & 3,48 & 183 & 286 & $-2,220$ & 0,027 \\
\hline \multirow{2}{*}{$\begin{array}{l}\text { online social } \\
\text { networks }\end{array}$} & Objectivity & 2,72 & 2,91 & 157 & 285 & $-2,578$ & 0,010 \\
\hline & Journalistic opinions & 3,30 & 3,48 & 166 & 303 & $-2,337$ & 0,020 \\
\hline
\end{tabular}

*All items of trust dimensions were recoded to the same scale, where 1 means lowest trust and 5 means highest trust. The trust dimension "distrust" is named negatively because it was computed from primarily negative statements; values were later recoded, so higher values means lower distrust and the opposite. 
These findings are in line with the findings of Mulder (1980) that audiences put less stress on credibility concerns in the case of entertainment media compared to information media. Whether and to what degree the news programme of POP TV is closer to the tabloid format than that of the public broadcaster is open to debate, yet overall, news programming comprises a lower share of POP TV's programming than it does in the case of the public broadcaster. In that sense, it can be said to be a more entertainment-oriented medium. Higher trust can also be found in followers of the internet news site dnevnik.si (they have higher trust in selection of topics), followers of the daily newspaper Večer and users that gain information through personal contacts (they have lower levels of distrust).

On the other side, the readers of the political weeklies Reporter and Demokracija have lower levels of trust in journalism (in general and on all four dimensions separately) than those who do not read these media. Readers of the financial weekly Finance also have lower trust in general and lower trust in objectivity. All three papers can be said to have a right-wing orientation, with Reporter and Demokracija leaning strongly towards Janez Janša's Slovenian Democratic Party (SDS), especially Demokracija, which is partially owned by the party. In the case of Reporter, Mance (2014) has found strong links on social media (specifically granting of relevance through likes and retweets on Twitter) between journalists of Reporter and key figures of the SDS party. Finance leans more broadly towards a pro-business, free-market ideology but is not aligned with a single political party. These results are similar to those found in the US by Jones (2004), who found that trust in media is connected with party affiliation, ideology and talk radio listening; those who identified as strong republicans, those who identified as strongly conservative ideologically and those who regularly listen to political talk radio exhibit particularly low levels of trust in the media. Comparing followers and non-followers, lower trust is also associated with the website 24ur.si (the most visited news website in Slovenia, which is operated by the same company as the television channel POP TV), the internet site of national broadcaster rtvslo.si, the third program of the national broadcaster ARS and national television program TV SLO 3, which covers sessions of parliamentary bodies and is mainly focused on political discussions.

\section{RQ3: Trust in journalism by channel}

We conducted a multiple linear regression analysis to check the impact of trust in journalism on frequency of media use in order to be able to control for the influence of a range of demographic variables. The independent variables of the four regression models are as follows: frequency of television viewing for informative purposes, frequency of radio listening for informative purposes, frequency of print reading for informative purposes and frequency of internet use for informative pur- 
Medij. istraž. (god. 22, br. 1) 2016. (41-63)

Table 6. Correlations between trust in journalism and media use by channel

(standardized regression coefficients, controlling for age, education, gender, and size of place of residence)

Tablica 6. Korelacije između povjerenja u novinarstvo i korištenja medijskih kanala (standardizirani regresijski koeficijenti, kontroliranje za godine, obrazovanje, spol i veličinu mjesta obitavanja)

\begin{tabular}{|l|l|l|}
\hline How many days in the average week do you ... & Trust in journalism \\
\hline \multirow{2}{*}{ watch informative shows on television? } & $\beta$ & 0,095 \\
\cline { 2 - 3 } & $\mathrm{t}$ & 2,05 \\
\cline { 2 - 3 } & Sig. & 0,041 \\
\hline read print media? & $\beta$ & $-0,006$ \\
\cline { 2 - 3 } & $\mathrm{t}$ & $-0,114$ \\
\cline { 2 - 3 } & Sig. & 0,909 \\
\hline \multirow{2}{*}{ listen to informative shows on the radio? } & $\beta$ & $-0,028$ \\
\cline { 2 - 3 } & t & $-0,556$ \\
\cline { 2 - 3 } & Sig. & 0,578 \\
\hline \multirow{2}{*}{$\begin{array}{l}\text { use the internet to follow information about current } \\
\text { affairs? }\end{array}$} & $\beta$ & $-0,043$ \\
\cline { 2 - 3 } & t & $-0,705$ \\
\cline { 2 - 3 } & Sig. & 0,481 \\
\hline
\end{tabular}

poses. The independent variable in all of these models was trust in journalism, and the control variables were age, education, gender and size of the participant's place of residence. Dummy variables were created for gender (reference category is male) and size of place of residence (reference category is less than 500 inhabitants).

When controlling for age, education, gender and size of place of residence, the connections between trust in journalism and frequency of media use are very weak. Only one of them, namely the frequency of television viewing for informative purposes, is statistically significant $(p=0,041)$. Yet it is still very weak $(\beta=0,095)$.

\section{Discussion}

Trust in journalism is not associated with frequency of media use (except in the case of television as mentioned above), indicating that trust is not an important predictor of media use, though it might have an important impact on information processing. This counterintuitive finding can be explained by taking into account the fact that audiences do not watch informative content merely to inform themselves; they have other motivations that might override credibility concerns. For example, they might 
follow media primarily for entertainment purposes and consequently put less emphasis on the quality of the received information.

As Greenberg and Roloff (in Mulder, 1980) have claimed, audiences tend to approach and process information differently depending on the channel; they approach television primarily for entertainment and newspapers primarily for information. This has implications for trust as well since audiences in an entertainment processing mode will be less attentive to credibility cues, such as news errors, than those in an information processing mode (Ibid.). Mulder's (1980) research confirms this claim - he found that audiences tend to approach newspaper reading more actively than television viewing and that credibility assessments differ regarding whether audience members approach news actively or passively.

These findings can help explain why we found a weak positive correlation between television news exposure and trust in journalism. It could be that audiences turn to television not because they expect the best quality information but rather the opposite - namely, that they approach television news less critically, focus less attention on credibility concerns and, therefore, develop a higher degree of trust in journalism. The fact that those respondents who follow the commercial television channel POP TV and the tabloid Slovenske Novice exhibit a higher trust in journalistic objectivity compared to those respondents who do not follow these media is also in line with this interpretation.

The topic of Janez Janša and exposure to media that are favourable to him and his SDS party is negatively connected to trust in journalism. This phenomenon can be partly explained by the elaboration likelihood model (Petty and Caccioppo, 1986), according to which highly involved individuals tend to process new information in a way that maintains and confirms their original opinion by 1) taking information consistent with their views (information that falls within a narrow range of acceptance) as simply veridical and embracing it, and 2) judging counter-attitudinal information to be the product of biased, misguided or ill-informed sources and rejecting it (Petty and Caccioppo, 1986; Gunther 1992). Highly partisan audiences will, therefore, tend to react to dissonant information by lowering the trustworthiness assessment of the source of such information.

Nonetheless, lower levels of trust are not simply a function of partisanship as such. Our results suggest that they are at least more pronounced with right-wing political positions, and specifically those associated with the SDS party. In the case of the ideologically left-leaning weekly Mladina, for example, the differences in trust levels between readers and non-readers were small and statistically non-significant, while in the case of its online edition, mladina.si, users exhibited an even lower level of distrust than non-users. Two factors can help to explain this phenomenon. One is that Janša himself and his party frequently employ charges of supposed 
mainstream media bias against them as a political strategy, and they have been doing so for years. The second factor is that the party actively tries to promote itself through media that are under their more-or-less direct control, as well as using social media to strengthen their messages.

By stripping away the boundaries between journalism and political groups and excluding dissident voices, this "coalition" pattern (Mance, 2014) of mutual systematic validation of importance gives rise to a "filter bubble" phenomenon (Pariser, 2011), thus filtering information inconsistent with the parties' positions. The multiplication of similar opinions can lead to their strengthening - the "echo chamber" effect - which in turn supports the culture of polarization of the media and political space (Sunstein 2001; Conover et al. 2011).

Therefore, it is not only commercialization and technological change that are driving media fragmentation and audience segmentation but also political actors, who can use these trends to their advantage. In a situation where followers of certain political parties react to dissonant information not by re-examining their own opinions and engaging in dialogue but by reducing their amount of trust in the source of such information, these parties are inoculated against critique and have a higher chance of retaining the support of their followers.

This trend has worrying implications for democracy. Fragmentation of media channels and segmentation of audiences means not only that citizens are less likely to be confronted with differing viewpoints and opinions but also that trust in journalism is being lessened, particularly with partisan audiences. Even when such audiences are being exposed to alternative information, they face them with a priori scepticism, and dissonant information might simply serve to confirm that scepticism. Thereby, a vicious spiral is created wherein the availability of more and better information might not serve to enlighten citizens but, instead, to paradoxically confirm and strengthen existing prejudices.

\section{ENDNOTE}

1 If respondents were not able to name a topic, the interviewer asked them whether they had followed any of the proceeding topics (in this order): the privatisation of the national telecommunications company (Telekom), the migration crisis in the Mediterranean, the Greek public debt crisis, the corruption scandal in healthcare and the constitutional court ruling on the mandate of Janez Janša. These topics are based upon a qualified estimate of the research team of the Journalism and the Internet Project regarding which topics were most salient in the mass media in the months immediately preceding the survey period. 
Connections Betwen Trust in Journalism and Patterns of Media Use

\section{LITERATURE}

Abel, J. D. \& Wirth, M. O. (1977) "Newspaper vs. TV credibility for local news", Journalism Quarterly, 54 (2), 371-375.

Berlo, D. K, Lemert, J. B. \& Mertz, R. J. (1969) "Dimensions for evaluating the acceptability of message sources”, Public Opinion Quarterly, 33: 563-76.

Blumler J. G. (2010) “The two-legged Crisis of Journalism”, Journalism Studies $11(4), 439-441$.

Bohman, J. (2004). "Expanding Dialogue: The Internet, the Public Sphere and Prospects for Transnational Democracy", 131-155. In: J. Habermas, N. Crossley and J. M. Roberts: After Habermas: New Perspectives on the Public Sphere, Oxford, UK: Blackwell Pub.

Browning, N. \& Sweetser K. D. (2014) “The Let Down Effect: Satisfaction, Motivation, and Credibility Assessments of Political Infotainment", American Behavioral Scientist 58(6), 810-826.

Conover, M. D., Ratkiewicz, J., Francisco, M., Goncalves, B., Menczer, F. \& Flammini, A. (2011), "Political Polarization on Twitter", Proceedings of the Fifth International AAAI Conference on Weblogs and Social Media. <https://www. aaai.org/ocs/index.php/ICWSM/ICWSM11/paper/view/2847/3275>

Chadwick, A. (2006) Internet Politics. States, Citizens and New Communication Technologies. Oxford: Oxford University Press.

Chaffee, S. H. (1972) “The interpersonal context of mass communication”, 95-120. In: F. G. Kline and P. J. Tichenor (Eds.): Current perspectives in mass communication research. Beverly Hills, CA: Sage.

Chaffee, S. H. (1982). "Mass media and interpersonal channels: Competitive, convergent, or complementary?”, 62-80. In: G. Gumpert and R. Cathcart (Eds.): Inter/media: Interpersonal communication in a media world. New York: Oxford University Press.

Chaffee, S. H., and M. J. Metzger. (2001) "The End of Mass Communication?" Mass Communication \& Society. 4 (4): 365-379.

Dahlgren, P. and Olsson, T. (2005) "The Micro-Meshes of Civic Cultures: Political Engagement and Media Use", paper presented to Making Use of Culture conference, Manchester University, Manchester.

Fenton, N. (2010) "Drowning or Waving? New Media, Journalism and Democracy “, 3-16. In: N. Fenton (ed.): New Media, Old News. London: Sage.

Franklin, B. (2014) “The Future of Journalism”, Journalism Studies, 15(5), 481-499.

Gaziano, C. \& McGrath, K. (1986) "Measuring the concept of credibility”, Journalism Quarterly, 63 (3), 451-462. 
Medij. istraž. (god. 22, br. 1) 2016. (41-63)

Grueskin B., Seave, A. \& Graves, L. (2012) The Story So Far: What We Know About the Business of Digital Journalism. <http://cjrarchive.org/img/posts/report/The_Story_So_Far.pdf>

Gunther, A. C. (1992) "Biased press or biased public? Attitudes toward media coverage of social groups", Public Opinion Quarterly, 56 (2), 147-167.

Habermas, J. (2014) Europe the faltering project. Cambridge: Polity Press.

Hallin, D. C. (2006) “The Passing of the 'High Modernism' of American Journalism Revisited", International Communication Association \& American Political Science Association, 16 (1) <http://www. jour. unr. edu/pcr/1601_2005_winter/ commentary_hallin. htm>

Hovland, C. I. \& Weiss, W. (1951) »The influence of source credibility on communication effectivenes«, Public Opinion Quarterly, 15, 633-650.

Johnson, T. J. \& Kaye, B. K. (1998) »Cruising is believing? Comparing internet and traditional sources on media credibility measures «, Journalism \& Mass Communication Quarterly 75 (2), 325-340.

Johnson, T. J. \& Kaye B. K. (2004) »Wag the blog: How reliance on traditional media and the internet influence credibility perceptions of weblogs among blog users«, Journalism \& Mass Communication Quarterly, 81 (3), 622-642.

Johnson, T. J. \& Kaye B. K. (2009) »In blog we trust? Deciphering credibility of components of the internet among politically interested internet users «, Computers in Human Behavior, 25 (1), 175-182.

Johnson, T J., Kaye, B. K., Bichard, S. L., \& Wong, W. J. (2007) »Every blog has its day: Politically-interested Internet users' perceptions of blog credibility«, Journal of Computer Mediated Communication, 13 (1), 100-122.

Jones, J. \& Salter L. (2012) Digital Journalism. New York: Sage.

Jones, D. A. (2004) »Why Americans don't trust the media«, Press/politics, 9 (2), 60-75.

Katz, E. (1996) »And Deliver Us from Segmentation«, Annals of the American Academy of Political and Social Science, 546, 22-33.

Kiousis, S. (2001) »Public trust or mistrust? Perceptions of media credibility in the information age«, Mass Communication \& Society, 4 (4), 381-403.

Luhmann, N. (1968) Vertrauen: ein Mechanismus der Reduktion sozialer Komplexität. Stuttgart: Ferdinand Enke Verlag.

Mance, B. (2014) »Odnosi med novinarji in politiki na Twitterju: od profesionalizma do ,odmevne komore"«. Javnost - The Public, 21 (Suplement), 23-40.

Mancini, P. (2013) »Media Fragmentation, Party System, and Democracy«, The International Journal of Press/Politics, 18 (1), 43-60. 
Markham, D. (1968) »The dimensions of source credibility of television newscasters«, Journal of communication, 18, 57-64.

Matthes, J. \& Kohring M. (2003) “Operationalisierung von Vertrauen in Journalismus”, Medien \& Kommunikationswissenschaft, 51 (1), 5-23.

McKnight, D. H. \& Chervany, N.L. (1996) The meanings of trust. Minnesota: MIRSC, University of Minnesota.

McLeod, J. M., Rush R. R., \& Friederich K. H.. 1969. "The Mass Media and Political Information in Quito, Ecuador". Public Opinion Quarterly. 32 (4), 575-587.

Metzger, M. J. \& Flanagin, A. J. (2000)»Perceptions of internet information credibility«, Journalism \& Mass Communication Quarterly 77 (3), 515-540.

Metzger, M.J., Flanagin, A. J., \& Zwarun, L. (2003) „College student Web use, perceptions of information credibility, and verification behaviour", Computers \& Education 41, 271-290.

Metzger, M. J., Flanagin, A. J., Eyal, K., Lemus, D. R. \& McCann, R. (2003) “Credibility for the 21 st century: Integrating perspectives on source, message and media credibility in the contemporary media environment", 293-335. In: Kalfleisch P. J. (ed.): Communication Yearbook, Vol. 27. Mahwah, New Jersey: Lawrence Erlbaum.

Mitchell, A., Gottfried, J., Kiley, J. \& Matsa, K. E. (2014) Political Polarization \& Media Habits. Pew Research Center. <http://www. journalism. org/2014/10/21/ political-polarization-media-habits/ $>$

Moody, K. E. (2011) “Credibility or convenience? Political information choices in a media-saturated environment", Media international Australia, 140, 35-46.

Mulder, R. (1980) "Media credibility: A use-gratification approach", Journalism Quarterly 57 (3), 474-477.

Nah, S., \& Chung, D. S. (2011) "When citizens meet both professional and citizen journalists: Social trust, media credibility, and perceived journalistic roles among online community news readers", Journalism, 13 (6), 714-730.

Newhagen, J. \& Nass, C. (1989) "Differential criteria for evaluating credibility of newspapers and TV news", Journalism quaterly, 65, 567-572.

Osgood, C. E. \& Tannenbaum, P. H. (1955) "The principle of congruity in the prediction of attitude change", Psychological review 62, 42-55.

Pariser, E. (2011). The filter bubble: What the Internet is hiding from you. New York: Penguin Press.

Petty, R. E., and Cacciopo, J. T. (1986) Communication and persuasion: Central and peripheral routes to attitude change. New York: Springer. 
Rimmer, T. \& Weaver, D. (1987) "Different questions, different answers? Media use and media credibility", Journalism Quarterly 64, 28-36.

Russial, J., Laufer P. \& Wasko J. (2015) »Journalism in Crisis?« Javnost - The Public, 22 (4), 299-312.

Skalski, P., Tamborini, R., Glazer, E., \& Smith, S. (2009)»Effects of humor on presence and recall of persuasive messages. « Communication Quarterly, 57 (2), 136-153.

Splichal, S. (2014) "Konec koncev - novinarstvo". In: K. Erjavec \& M. Poler Kovačič (eds.): 50 let študija novinarstva na Slovenskem, 43-68. Ljubljana: FDV.

Stroud Jomini, N. (2011) Niche News: The Politics of News Choice. Oxford: Oxford University Press.

Sunstein, C. (2001) Republic.com. Princeton: Princeton University Press.

Sztompka, P. (1999) Trust: a sociological theory. Cambridge: Cambridge University Press.

Thorson, E. \& Moore, J. (1996) »The circle of synergy: Theoretical perspectives and an evolving IMC agenda«, 333-354. In: E. Thorson \& J. Moore (Eds.): Integrated communication: Synergy of persuasive voices. Mahwah, New Jersey: Lawrence Erlbaum Associates.

Westley, B. H. \& Severin, W. J. (1964) »Some correlates of media credibility«, Journalism Quarterly, 41, 325-335. 


\section{Veza između povjerenja u novinarstvo i korištenja medija}

\section{Sašo Slaček Brlek}

Jožica Zajc

Boris Mance

\section{SAŽETAK}

Članak istražuje veze između povjerenja u novinarstvo i korištenja medija. Autori pronalaze kako je veza između učestalosti korištenja medija u svrhu informiranja i povjerenja u novinarstvo vrlo slaba: ona je statistički značajna na razini 0,5 za gledanje televizije, ali ne i za slušanje radija, čitanje novina ili korištenje interneta. Autori pronalaze indikacije polariziranosti po stranačkim linijama, s obzirom na to da oni koji prate desno orijentirane medije (osobito one vezane uz Slovensku Demokratsku Stranku) pokazuju nižu razinu povjerenja u novinarstvo.

Ključne riječi: povjerenje u novinarstvo, medijska fragmentacija, stranačka polarizacija, potrošnja vijesti 